вития сельского хозяйства на 2017-2025 годы: материалы Междунар. науч.-практ. конф. - Курган, 2018. - С. 605-608.

14. Родин П.В., Чучин В.Н., Молчанов А.В. Ферментные и селеносодержащие препараты в профилактике гестоза супоросных свиноматок // Вопросы нормативно-правового регулирования в ветеринарии. - 2015. - № 2. - С. 236-237.

15. Effects of paenibacillus-based probiotic (bacispecin) on growth performance, gut microflora and hematology indices in goslings / F.S. Khaziakhmetov, A.F. Khabirov, R.Kh. Avzalov, G.R. Tsapalova, Kh. Kh. Tagirov, Sh. Sh. Giniyatullin, A.E. Andreeva, F.M. Gafarova, F.A. Gafarov // Journal of Engineering and Applied Sciences, 2018, T. 13,
No. 8, P. 6541-6545.

Хазиахметов Фаил Сабирянович, $\partial-p$ c. $-x$. наук, проф. кафедры «Физиология, биохимия и кормление животных», Башкирский государственный аграрный университет. Россия.

Хабиров Айрат Фаритович, канд. биол. наук, доизен, зав. кафедрой «Физиология, биохимия и кормление животных», Башкирский государственный аграрный университет. Россия.

450001, г. Уфа, ул. 50-летия Октября, 34.

Тел.: (347) 228-91-77; e-mail: bgau@ufanet.ru.

Ключевые слова: телята; пробиотик; живая масса; среднесуточный прирост; коэффициент переваримости; кровь; экономическая эффективность.

\title{
APPLICATION OF PROBIOTIC “STIMIX ZOOSTIM” IN CALVES MANAGEMENT
}

Khaziahmetov Fail Sabiryanovich, Doctor of Agricultural Sciences, Professor of the chair "Physiology, Biochemistry and Feeding of Animals", Bashkir State Agrarian University. Russia.

Khabirov Airat Faritovich, Candidate of Biological Sciences, Associate Professor, Head of the chair "Physiology, Biochemistry and Feeding of Animals", Bashkir State Agrarian University. Russia.

Keywords: calves; probiotic; body weight; average daily weight gain; coefficient of digestibility; blood; economic effect.

Introduction to the diets of calves of the dairyperiod of probiotic "Stimix Zoostim" based on the microorganisms Escherichia coli, Lactobacillus acidophilus, Saccharomyces cerevisiae, Bacillus subtilis, Azotobakter vinelandii, Azotobakter chroococcum in a dose of $10 \mathrm{ml}$ per head per day from 10 to 20 days; at a dose of $15 \mathrm{ml}$ - at the age of 21 to 90 days contributed to an increase in the average daily gain of $8.9 \%$, a decrease in the cost of feed by $8.1 \%$ compared with the first control group, with absolute preservation of calves. The protein digestibility coefficient was $84.9 \%$ (P 0.05), which was higher by 3.8 absolute percent. Within the physiological norm, such indicators as erythrocytes, hemoglobin, and -globulins have improved. These changes in the blood composition indicate a higher level of natural resistance and are characteristic of intensively growing calves. The results of the production audit showed that the economic effect per 1 head was 149.23 rubles.

UDK636.084:636.085.12

\section{USE OF HUMIC ACIDS IN PIG PRODUCTION}

\author{
KACHEPA Upile Emmanuella, Saratov state agrarian university named after N.I. Vavilov \\ MANIESON Victor Emmanuel, Saratov state agrarian university named after N.I. Vavilov \\ VASILIEV Alexey Alexeevich, Saratov state agrarian university named after N.I. Vavilov \\ SIVOKHINA Lyubov Alekcandrovna, Saratov state agrarian university named after N.I. Vavilov
}

The article presents the literature data on the results of the use of humic acids and substances derived from them as feed additives for pigs. Some ways of application of humic acids in feeding of pigs and data of the previous researches are described. At the end of the article the conclusion about the influence of humic acids on the productivity and safety of pigs is considered, the proposals for further more advanced scientific research are given.

The search for good quality feed with nutritional value for pig production has been on-going for many years, as of late many studies have been conducted on humic acids, mainly known for its advantageous use in plant growth and sustainability, is now being studied for its effects on using it as an additive in livestock feed [1].

Humic acid is highly concentrated organic material derived from leonardite, an oxygenated product of lignite, rich in humic acids and various types of elements, such as natural amino ac- ids, minerals and vitamins just to mention a few [4, 6-8].

Past studies have shown humic acid has proven to have fascinating properties tied to the production and health of livestock, and is rapidly developing in the animal husbandry sector as a healthier and safer alternative feed additives, humic substance (including humates, fulvates, humic acid and fulvic acid) has been used in animal husbandry to improve the economy and ecology of animal production by increasing growth rate, improving feed efficiency and 
immunity, diminishing the risk of disease $[5,11]$.

Humic acids are known to have great benefits when it comes to the gastro-intestinal tract and overall health of an animal; they stabilise intestinal flora to promote feed efficiency, provide protective film on the mucous lining of the gastro-intestinal tract to assist in the prevention of excessive water loss through the intestine and helps facilitate metabolic actions.

Due to humic acid having a cation exchange capacity of 450, it provides an absorptive capacity close to that of activated charcoal [2], meaning it can soak up and isolate toxins before they cause any damage to cells and often reducing toxic substances caused by infectious microbes.

In a study conducted in 2007 in Dankook university, Korea a total of forty-eight pigs were used to determine the effects of humic substances on growth performance, blood characteristics, and meat quality with the principal that humic substances have been used as an antidiarrheal, analgesic, immunostimulatory, and antimicrobial agents in veterinary practices in Europe [10]. The finishing pigs were assigned by weight to three treatments. The dietary treatments included: 1) Control (CON; basal diet), 2) HS1 (basal diet $+5 \%$ humic substances) and 3) HS2 (basal diet $+10 \%$ humic substances). Results of the whole experimental period showed that addition of $10 \%$ HS to the diet, significantly increased average daily gain (ADG) and gain/feed (G:F) (Pb0.05). At the end of the experiment, the relative lymphocyte counts (\% of total white blood cells) of pigs fed HS2 diet were higher $(\mathrm{Pb0.05})$ than that of pigs fed CON diet. The Minolta color parameter of pigs fed HS2 was similar to that of pigs fed HS1, however, it was higher $(\mathrm{Pb} 0.05)$ than that of pigs fed CON diet. The inclusion of either $5 \%$ or $10 \%$ HS significantly decreased backfat thickness (Pb0.05). The marbling score was increased significantly ( $\mathrm{Pb0.05)}$ when diets were supplemented with HS at a level of 10 $\%$. The results of this study suggest that HS might be utilized as a feed additive in the diet that could improve growth performance, relative lymphocyte counts and meat quality [9].

In 2009 an experiment was conducted on piglets in the veterinary research institute in Brno, Czech Republic The purpose of the study was to assess the effect of a 21-day feeding of a diet with $1 \%$ inclusion of sodium humate $(\mathrm{HNa})$ on the content of trace elements (copper, zinc, selenium, manganese, cobalt) in tissues of weaned piglets, their efficiency and biochemical indicators. Significantly lower content of manganese in livers $(\mathrm{P}<0.01)$ and kidneys $(\mathrm{P}<0.05)$ was detected in piglets fed the $1 \% \mathrm{HNa}$ supplemented diet in comparison with control, non-treated animals. The concentrations of selenium in blood serum $(\mathrm{P}<0.05)$ and muscular tissue $(\mathrm{P}<0.01)$ were significantly lower in experimental animals. Significantly higher daily body weight gain was detected in experimental piglets compared to control animals ( 0.303 vs. $0.258 \mathrm{~kg}, \mathrm{P}<0.05)$ and the feed conversion rate was increased by $6.4 \%$ (1.60 vs. $1.71 \mathrm{~kg})$. Increased concentrations of blood serum glucose, triacylglycerols $(\mathrm{P}<0.01)$, calcium and iron $(\mathrm{P}<0.05)$ were detected in experimental vs. control piglets. The results of the present study indicated that despite a positive effect, sodium humate caused a decrease in concentration of physiologically important manganese and selenium in the tissues [12].

In 2006 five experiments were conducted to test the effects of various dietary humic substances which can include most of the OM in many soils (Goh and Reid, 1975) but specifically include humic acid, fulvic acid, and humin as major constituents as well as several minerals such as iron, manganese, copper, and zinc (Aiken et al., 1985) on pig growth, carcass characteristics, and ammonia emission from manure. In experiment 1,120 pigs were allotted to 3 dietary treatments without HS (the control) or with HS1 at 0.5 and $1.0 \%$ and fed diets, based on a 5-phase feeding program, from weaning ( $\mathrm{d} 21.3 \pm$ \pm 0.3 of age) to $60 \mathrm{~kg}$ of body weight. In experiment. 2 and 3, 384 pigs (192 for each experiment) were allotted to 3 dietary treatments without HS, with HS1, or with HS2 $(0.5 \%)$ for Exp. 2 and without HS, or with HS3 or HS4 (0.5 \%) for Exp. 3. Pigs were fed diets, based on a 6-phase feeding program, from weaning $(25.4 \pm 0.2$ and $23.6 \pm 0.3 \mathrm{~d}$ of age for Exp. 2 and 3, respectively) to $110 \mathrm{~kg}$ of body weight. In Exp. 4, 96 pigs were weaned at $22.1 \pm 0.2 \mathrm{~d}$ of age and allotted to 2 treatments without or with HS1 at $0.5 \%$, and in Exp. 596 pigs were weaned at $20.9 \pm$ $\pm 0.3 \mathrm{~d}$ of age and allotted to 3 treatments without HS, or with HS3 or HS4 $0.5 \%$. Pigs were fed the diets for 2 weeks before they were moved to an environmental chamber to measure aerial ammonia and hydrogen sulfide for $48 \mathrm{~h}$ at 5-min intervals. The results that in Exp.1, pigs fed diets with HS1 at $0.5 \%$ had greater $(11 \%, \mathrm{P}<0.05)$ ADG during phase 3 and greater $(\mathrm{P}<0.05) \mathrm{G}: \mathrm{F}$ during phases 3 and 5 than control pigs. In Exp. 2, pigs fed diets with HS1 or HS2 at $0.5 \%$ had greater $(\mathrm{P}<0.05)$ ADG and G:F than control pigs during the entire feeding period, whereas in Exp. 3 HS3 or HS4 did not improve pig growth performance. Ammonia emission from manure was reduced by 18 or $16 \%$ when pigs were fed diets with HS1 $(\mathrm{P}=0.067)$ or HS4 $(\mathrm{P}=0.054)$, respectively [3].

Numerous other studies reported the similar results in the effects of humic acids in pig feed, other results recorded showed low morality rates in piglets at birth as well as an increase in the number of piglets and a faster recovery period post-partum.

It has become evident with the number of stud- 
ies conducted on the effects of humic acids that the conclusions drawn are that of mostly positive results although we still do not know enough on the effects of humic acids in pigs.

More research needs to be conducted on the effects of humic acids in relation to it being an additive in pig feed, more studies must be conducted to determine how much of the humic acid can be mixed in with the feed, how often can the humic acid can be used and most importantly to find any disadvantages in the use of humic to help identify solutions to any problems presented by the application of humic acids in feed.

\section{LITERATURE CITED}

1. Значение, теория и практика использования гуминовых кислот в животноводстве / А.А. Васильев [и др.] // Аграрный научный журнал. - 2018. № 1. - C. 3-6.

2. Gheler T.R., Araujo L.F., da Silva C.C., Gomes G.A., Prata M.F. Gomide C.A. (2009). Use of benzoic acid for piglets // Rev Bras Zootec, 2009. URL scielo. br.com.

3. Ji F., McGlone J.J., Kim S.W. Effects of dietary humic substances on pig growth performance, carcass characteristics, and ammonia emission // Journal of Animal Science 84, 2006, 2482-2490.

4. Kaevska M., Lorencova A., Videnska P., Sedlar K., Provaznik I., Trckova M. Effect of sodium humate and zinc oxide used in prophylaxis of post-weaning diarrhoea on faecal microbiota composition in weaned piglets // Veterinarni Medicina, 2016, 61, 328-336.

5. Islam K.M.S., Schuhmacher A., Gropp J.M. Humic Acid Substances in Animal Agriculture Institute of Animal Nutrition. URL: citeseerx.ist.psu.edu>viewdoc/ download...

6. Kunavue N., Lien T.F. Effects of Fulvic Acid and Probiotic on Growth Performance, Nutrient Digestibility, Blood Parameters and Immunity of Pigs // J. Anim Sci Adv 2012, 2(8), 711-721.
7. Trckova M. et al. Effects of peat feeding on the performance and health status of fattening pigs and environmentally derived mycobacteria // Veterinarni Medicina, 51, 2006 (12): 533-543.

8. Manieson V.E., Kachepa U.E., Vasiliev A.A. The use of humic acids in cattle production // Agrarian Scientific Journal, 2018, 5, 35-36.

9. Wang Q. et al. Effects of supplemental humic substances on growth performance, blood characteristics and meat quality in finishing pigs, URL:e-sciencecentral.org.

10. Thiel K.D., Klocking R., Schweizer H., Sprossig M. Invitro studies of the antiviral activity of ammonium humate against herpes simplex virus type 1 and type 2 . Zentralbl Bakteriol, 1977, 239, 304-321.

11. Vucskits A.V., Hullar I., Bersenyi A., Andrasofszky E., Kulcsar M., Szabo J. Effect of fulvic and humic acids on performance, immune response and thyroid function in rats // J. Anim. Physiol. Anim. Nutr. (Berl). 2010. Vol. 94, N 6. P. 721-728.

12. Zdenek Zraly, Bohumila Pisarikova. Effect of Sodium Humate on the Content of Trace Elements in Organs of Weaned Piglets, URL: actavet.vfu.cZ>/

Kachepa Upile Emmanuella, Student, Saratov State Agrarian University named after N.I. Vavilov. Russia.

Manieson Victor Emmanuel, Student, Saratov State Agrarian University named after N.I. Vavilov. Russia.

Vasiliev Alexey Alexeevich, Doctor of Agricultural Sciences, Professor, Head of the chair "Feeding, Zoohygiene and Aguaculture", Saratov State Agrarian University named after N.I. Vavilov. Russia.

Sivokhina Lyubov Aleksandrovna, Candidate. of Agricultural Sciences, Associate Professor of the chair "Feeding, Zoohygiene and Aquaculture", Saratov state Agrarian University named after N.I. Vavilov. Russia.

Keywords: humic acids; humic substances; feed additives; pigs; piglets; growth performance.

\section{ПРИМЕНЕНИЕ ГУМИНОВЫХ КИСЛОТ В СКОТОВОДСТВЕ}

Качепа Упиле Эммануелла, студент факультета ветеринарной медицины, пищевых и биотехнологий, Саратовский государственный аграрный университет имени Н.И. Вавилова. Россия.

Маниесон Виктор Эммануэль, студент факультета ветеринарной медицины, пищевых и биотехнологий, Саратовский государственный аграрный университет имени Н.И. Вавилова. Россия.

Васильев Алексей Алексеевич, $\partial-p$ c.- $x$. наук, проф., зав. кафедрой «Кормление, зоогичена и аквакультура», Саратовский государственный аграрный университет имени Н.И. Вавилова. Россия.

Сивохина Любовь Александровна, канд. с.-х. наук, доцент кафедры «Кормление, зоогигиена и аквакультура», Саратовский государственный аг- рарный университет имени Н.И. Вавилова. Россия.

Ключевые слова: гуминовые кислоты; кормовые добавки; свиньи; поросята; показатели роста.

Приводятся литературные данные о результатах использования гуминовых кислот и веществ, получаемых на их основе, в качестве кормовых добавок для свиней. Описань некоторые способы применения гуминовых кислот в кормлении свиней и данные предыдущих исследований. Проанализировано влияние гуминовых кислот на продуктивность и сохранность свиней, даны предложения для проведения дальнейших научных исследований. 